\title{
Águas que desenham Moçambique
}

Waters that draw Mozambique

1 Doutora em Letras, na área de concentração Teoria da literatura (PUCRS); professora adjunta no Instituto de Letras e Artes, na Universidade Federal do Rio Grande (FURG) (D) https://orcid.org/0000-0003-3757-0800 E-mail: claudiamartins@furg.br

Eutura em Letras, na área de concentração do GP "Literatura Imaginário; p Poéticas da Contemporaneidade" (FURG). É autora da tese intitulada: Águas de travessia: a matriz poética na obra de Mia Couto, defendida em 2016. (i) hitps.//orcid.org/0000-0003-0354-4137
RESUMO: Nos poemas escritos por Mia Couto, assim como na sua produção literária em geral, verificamos a presença da água como um fio condutor Em nossa percepção, a água é símbolo e/ou metáfora de múltiplos sentidos. Ela conduz o conhecimento, o tempo e a memória, renova e reestrutura a realidade do homem e do meio em que este vive. É o elemento transitório de que fala Gaston Bachelard, sendo ainda o símbolo cosmogônico da eternidade. Na poesia, em especial, se presencializa como personagem, cenário e tema. Sob a ótica do que designamos como águas moçambicanas, tomamos a produção poética do autor e constatamos que das águas eternas, passageiras, criadoras, destruidoras, reais ou simbólicas se nutrem vários poemas de Mia Couto.

Palavras-chave: Mia Couto; Poesia; Águas moçambicanas.

ABSTRACT: In the poems written by Mia Couto, as well as in his literary production in general, we can see the presence of water as a thread. In our perception, the water is a symbol and/or metaphor of multiple senses. It conducts the knowledge, the time and the memory, renews and restructures the reality of the man and of the environment in which he lives. It is the transitory element in which Gaston Bachelard talks, also being the cosmogonic symbol of the eternity. In the poetry, specially, presented as a character, scenario and theme. Under the optical of what we determine as Mozambican waters, we took the poetic production of the author and we realized that from the eternal waters, passenger, creating, destructive, real or symbolic are nourished several poems of Mia Couto.

Keywords: Mia Couto; Poetry; Mozambican waters.

Acredito, porém, que os rios que percorrem o imaginário do meu país cruzam os territórios universais e desembocam na alma do mundo.

${ }^{1}$ Trecho do livro E se Obama fosse africano? E outras interinvenções (COUTO, 2009, p. 11). 
$\mathrm{M}^{\mathrm{i}}$

a Couto realiza um poetar do mundo conhecido, constituído e construído a partir da sacralidade das águas, de onde vieram lógicas e sabedorias que se agregaram ao ser do poeta e falam, também, através do discurso do cronista, do contista e do romancista. As águas fazem parte do seu cotidiano, dos cenários onde vive, do amadurecimento do homem e da história de seu país. Na obra miacoutiana elas percorrem caminhos interiores, estando na voz de poetas, narradores e personagens; e exteriores enquanto contexto, mostrando-se na geografia dos homens e dos animais e, igualmente, são argumentos que norteiam ações e sentimentos desde tempos ancestrais.

A água é símbolo e metáfora, realidade e ficção e conduz o conhecimento, o tempo e a memória, renova e reestrutura, a partir do onírico, a realidade do homem e do meio em que ele vive. Ela é o elemento transitório de que nos fala o filósofo Gaston Bachelard (2002)², na obra A água e os sonhos, sendo ainda o símbolo cosmogônico da eternidade, que percorre todos os tempos ininterruptamente, carregando em si a mobilidade dos sonhos. Ainda, conforme Bachelard, "Sonha-se antes de contemplar. Antes de ser um espetáculo consciente, toda a paisagem é uma experiência onírica" (BACHELARD, 2002, p. 5). Em contraste ou em complemento com o fogo e com a terra, "a água é também um tipo de destino, [...] um destino essencial que metamorfoseia incessantemente a substância do ser" (BACHELARD, 2002, p. 6, grifo do autor.). Acompanhando o filósofo, temos a afirmativa de que a água "É o sangue da terra. A vida da terra. É a água que vai arrastar toda a paisagem para seu próprio destino” (BACHELARD, 2002, p. 65).

\footnotetext{
2 As análises da poética miacoutiana presentes neste artigo serão propostas sob o prisma de Bachelard (2002), no que se refere à água, e Bachelard (2000), no que concerne à memória. Por sua vez, Paz

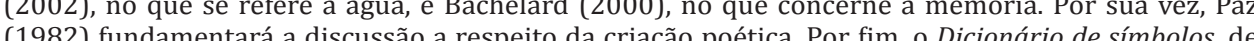
(1982) fundamentará a discussão a respeito da criaça poética. Por fin, o Dicionánio de símbolos, de discutidos.
}

As palavras soam interiores, as imagens se diluem e dissolvem dialogicamente, mas é no pano de fundo das águas moçambicanas que Mia Couto exerce o seu peculiar "fazer" literário. Como disse a sua voz poética: "Semente de toda a semente, / em palavra desaguei, / para sempre rio em busca de outra margem" (COUTO, 2011, p. 50) ${ }^{3}$. A sua voz de cronista retoma o rio/mar das águas que desenham Moçambique no continente africano e tecem os saberes da cultura da nação, para dizer que:

Dos lugares da terra prefiro os que são feitos de água. Como se a água desobedecesse ao retrato, como se o contorno fluído desses lugares os fizesse mais a jeito de serem lembrados. Afinal, toda a lembrança é líquida, uma mentira consentida. Estas são dez pinceladas, feitas de tempo e de vida. E de águas da minha terra (COUTO, 2010, p. 93) ${ }^{4}$.

O escritor miacoutiano nos fala da infância, onde os rios delineavam a paisagem:

Nasci e vivi entre meandros de rios, preguiçosas águas que se apegavam às margens. A estação ferroviária obedecia a essa líquida paisagem. 0 comboio era um barco e eu entendia porque se chamava "cais" àquela plataforma onde as mães agitavam os lenços brancos (COUTO, 2015, grifo do autor).

Em continuidade a essas considerações, lembramos que dois importantes marcos de água em Moçambique são o Oceano Índico - que banha todo o litoral - e o rio Zambeze - que cruza o país -, sobre os quais o escritor se refere em muitas ocasiões e que marcam presença em várias de suas obras. Outros rios, como o Tete, por exemplo, também são cenários de sua prosa e de seus versos, assim como lagos, ilhas, cataratas, nascentes, mangues e riachos, que geram belezas, tratam de mitos, contextualizam

3 Estrofe final do poema "Dilúvio", publicado em Tradutor de chuvas (COUTO, 2011, p. 49-50)

4 Trecho da crônica "As águas da terra", publicada em Pensageiro frequente (COUTO, 2010, p. 93-100). 
tragédias e registram importantes passagens de tempo da vida do escritor. A esse universo denominamos de águas moçambicanas.

Sobre algumas delas, mencionamos as seguintes palavras do autor:

Mais que obstáculo, o oceano Índico foi um caminho, um cruzamento de culturas. Por suas águas chegaram navegantes de outros continentes, de outras raças, de outras religiões. Na costa moçambicana os navios eram a agulha que costurava esse imenso pano onde ainda hoje se estampavam diversidades. Durante séculos não se procedeu apenas ao comércio de mercadorias, de línguas, de culturas e de genes. Construíram-se nações. Moçambique foi tecido do mar para o interior. A linha que costurou o nosso país veio da água, da viagem, do desejo de ser outro. A bandeira que nos cobre é um pano de muitos e variegados fios (COUTO, 2010, p. 67) 5 .

0 Zambeze é uma faca azul cortando a nação ao meio. 0 grande rio é uma fronteira, um ponto cardeal: acima dele, o Norte. Mas os rios não separam. Antes, costuram, verdadeiros alfaiates da Terra. Mesmo que estes costureiros por vezes se embriaguem e tropecem nas próprias margens, com vastas inundações (COUTO, 2010, p. 49) .

Empreendo aqui a imaginária viagem do nosso rio maior, da nascente à foz. Sigo de rio, sou Zambeze. Por quase três mil quilómetros vou zambezeando até [...] desaguar no mar. Olhando o rio me vejo, eu mesmo fluindo, em travessia de tempo. Essa viagem é sempre sem retorno? A poesia me dá o barco, mais um remo que é o sonho. E eu aprendo a navegar ao invés da corrente. Como se um outro rio fluísse em contratempo... (COUTO, 2010, p. 45). ${ }^{7}$

Gaston Bachelard (2000, p. 29), em A poética do espaço, sustenta que a memória do passado se presencializa no espaço físico, onde estariam "os belos fósseis de duração concretizados por longas permanências". Para ele, "o inconsciente permanece nos locais. As lembranças são imóveis, tanto mais

5 Trecho da crônica "Um mar de trocas, um oceano de mitos”, p. 63-67, sob o subtítulo “Um pano de muitas linhas', publicada em Pensageiro frequente, 2010.

6 Trecho da crônica "Zambezeando", p. 45-49, sob o subtítulo de 'Foz (o delta)', p. 49, publicada em Precho da crônica "Zambeiro frequente, 2010.

7 Trecho da crônica "Zambezeando", p. 45-49, publicada em Pensageiro frequente, 2010. sólidas quanto mais bem espacializadas" (BACHELARD, 2000, p. 29). É essa a perspectiva que encontramos nas águas miacoutianas e seguimos neste artigo, especificamente, em duas de suas obras poéticas: Raiz de orvalho e outros poemas e Idades cidades divindades.

O primeiro livro de Mia Couto com o nome de Raiz de orvalho e contendo 40 poemas foi publicado em 1983, em Maputo. Em 1999, com o título de Raiz de orvalho e outros poemas aparece sua segunda obra em poesia, já vinculada à editora Caminho, de Lisboa. Neste livro, o poeta revisita o primeiro, fazendo algumas alterações como a retirada e/ou inclusão de alguns poemas ${ }^{8}$. Nas suas palavras, “[...] ao aceder a publicar a minha poesia inicial eu senti que devia escolher apenas alguns dos poemas da primeira versão [...]. Acrescentei outros versos inéditos, todos datados da década de oitenta" (COUTO, 1999, p. 7). No texto de abertura, intitulado "Palavras iniciais", de Raiz de orvalho e outros poemas", Mia Couto explicita que os versos que compõem o livro têm a simbologia de raiz fundadora:

Assumo estes versos como parte do meu percurso. Foi daqui que eu parti a desvendar outros terrenos. 0 que me liga a este livro não é apenas memória. Mas o reconhecimento de que, sem esta escrita, eu nunca experimentaria outras dimensões da palavra (COUTO, 1999, p. 7).

O título do livro inaugura uma sequência de significações especiais encontrada na obra do autor, que inicia, igualmente, a sua profunda relação com a água, no caso com a semântica do orvalho. Sob essa ótica, acompanhamos a estudiosa Carmen Lucia Tindó Ribeiro Secco (2006) em sua análise:

${ }^{8}$ Na edição de 1999, foram repetidos 25 poemas constantes na primeira e acrescentados 29.

9 Para a realização da análise dos poemas selecionados de Raiz de orvalho, consultaremos a versão original e para os que constam nessa e na de 1999, revista pelo autor, utilizaremos a última. 
A metáfora da "raiz de orvalho" é rica em significações. Raiz remete ao que é profundo, ao que alimenta, à parte oculta que suga os substratos necessários à vida; significa também que o sustenta, o que prende, sendo, desse modo, vínculo, liame. Representa ainda o germe, o princípio, o que se reproduz. 0 poema, assim, se faz rizoma, rede tecida de polissemias e sentimentos. "Raiz exposta", é uma poesia que se desnuda, e, como um nervo descoberto, provoca aguda dor a despertar sonâmbulas consciências. Poesia do amor, da ternura que faz tremer, acordando silenciosas emoções. Palavras de orvalho, "trêmulas gotas" de sonho a refrescarem a terra morta, anunciam a aurora e a liberdade. Água da palavra, tremeluzindo no sobressalto inaugural do verbo criador, a poesia de Mia Couto busca, portanto, através da beleza estética, a raiz do humano que se eterniza na expressão de cada homem e de cada verso (SECCO, 2006, p. 275, grifos da autora).

O poema título, que reproduzimos a seguir, foi publicado na edição de 1983 e na de 1999. Nele o eu lírico expõe a tentativa de reinvenção de si mesmo, quando o sonho se propõe a ser delírio, forte, intenso e criativo, buscando um destino no mar, que funciona como uma janela - talvez uma porta - para o mundo da poesia. O orvalho surge como origem da água que (trans)corre como o passar do tempo; é a lágrima do céu conforme propõem Chevalier e Gheerbrant (1996, p. 664), que o associam à chuva, podendo ter o significado de benção divina, água que provém do coração e atravessa o homem. É uma água pura, da origem, água-mãe que envolve, embala e suaviza, associada à Lua que aclara o olhar com a feminilidade, como proteção e guia rumo a eternidade.

\section{Raiz de orvalho}

Sou agora menos eu

e os sonhos

que sonhara ter

Quem me dera acontecer

essa morte de que se não morre

e para um outro fruto

me tentar seiva ascendendo

porque perdi a audácia

do meu próprio destino

soltei a ânsia

do meu próprio delírio

e agora sinto

tudo o que os outros sentem

sofro do que eles não sofrem

anoiteço na sua lonjura

e vivendo na vida

que deles desertou

ofereço o mar

que em mim se abre

a viagem mil vezes adiada

De quando em quando me perco

na procura da raiz de orvalho

e se de mim me desencontro

foi porque de todos os homens

se tornaram todas as coisas

como se todas elas fossem

o eco das mãos

a casa dos gestos

como se todas as coisas

me olhassem

com os olhos de todos os homens

Assim me debruço

na janela do poema

escolho a minha própria neblina

e permito-me ouvir

o leve respirar dos objetos

sepultados em silêncio

e eu invento o que escrevo

escrevendo para me inventar

e tudo me adormece

porque tudo desperta

secreta voz da infância 
Amam-me demasiado

as coisas de que me lembro

e eu entrego-me

como se me furtasse

à sonolenta carícia

desse corpo que faço nascer

dos versos

a que livremente me condeno

Agosto 1982 (COUTO, 1999, p. 39-41) ${ }^{10}$.

A raiz de orvalho pode ser o princípio e o despertar para a eternidade, mas pode, igualmente, ser o sentir do poeta que fala ao coração dos outros, que reproduz o sentir desse outro em si mesmo; o eu lírico reverbera num eco constante que também é do outro, o poeta sente o mundo em suas palavras. Nesse sentido, destacamos as palavras de Carmen Secco, quando diz que: "A escritura poética é [...] o produto de uma semiose que funde, literariamente, lirismo e lucidez na captação do mundo e da existência" (SECCO, 1998, p. 160). Mia, enquanto poeta, divide com o mundo seus sentimentos e se expõe na "janela do poema", sob sua própria neblina, que pode ser seu sonho ou ser a névoa por detrás da qual se oculta sua inspiração. Nada é claro, tudo é pressentido. Nesses momentos, o poeta se abre para o universo ao redor e se torna real para si mesmo, enquanto inventa o que escreve e escreve para se inventar; assim nasce o poeta, surge esse ser que supre tudo e todos ao se entregar às palavras que vivem em si desde o seu princípio; assim nasce a escrita poética de Mia Couto, que se adensa na poesia e se expande na prosa. "Raiz de orvalho" é o início do que ele irá definir, mais tarde, como "[...] travessia de uma intangível fronteira: a realidade da poesia e a poesia da realidade" (COUTO, 2013, p. 199).

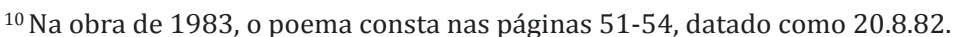

É a partir dos poemas inscritos, nesta obra inaugural, que o poeta se aventurou em outras escritas e, por consequência, desenvolveu sua trajetória e estabeleceu sua poética. Acompanhamos a opinião da estudiosa portuguesa Elena Brugioni (2012) quando ela afirma que "A comparação implícita que irá estabelecer-se entre a obra poética em análise e a produção de Mia Couto permitirá a individuação de algumas formulações relevantes" (BRUGIONI, 2012, p. 107), propiciando que se estabeleça uma reflexão "em torno das dinâmicas sui generis que configuram a(s) escrita(s) deste autor" (BRUGIONI, 2012, p. 107).

Na primeira edição de Raiz de orvalho, escolhemos como poema a ser analisado "As duas águas da água" (COUTO, 1983, p. 18), que traz à tona uma abrangência completa do eixo temático por nós priorizado: a água. Sobre a água, Chevalier e Gheerbrant (1996) afirmam que "As águas, massa indiferenciada, representando a infinidade dos possíveis, contêm todo o virtual, todo o informal, o germe dos germes, todas as promessas de desenvolvimento, mas também todas as ameaças de reabsorção" (CHEVALIER; GHEERBRANT, 1996, p. 15, grifos dos autores.). As águas do poema em pauta colocam em diálogo a geografia interior do homem moçambicano, quer seja o litorâneo, aberto para o outro que chega ou o interiorano, que viaja pelos rios interiores do país e de si mesmo com a capacidade de serem mutáveis, múltiplas e maleáveis, enquanto perenes. $\mathrm{O}$ homem se conecta do surgimento à partida pela água que é origem e destino e carrega em si a mítica relação da vida e da morte.

As duas águas, rio e mar, acariciam a terra que dividem e envolvem. $\mathrm{O}$ primeiro aprisionado pelas margens que só é liberto pela generosidade de outra água, a da chuva, que é água divina que inunda a terra. Simbolicamente, o rio, como "descida da corrente em direção ao oceano" (CHEVALIER; GHEERBRANT, 1996, p. 780), é o caminho da superação e do retorno ao Princípio. Ele percorre a terra como caminho de vida e morte, como ponto 
de origem humana e destino final. Já o mar, "imagem da indistinção original" (CHEVALIER; GHEERBRANT, 1996, p. 593), tanto dá origem quanto absorve o fim, é dinâmico, ora calmo e generoso e ora agitado e indomável.

O poeta, ser terreno e sedento, segue as águas doces e nelas busca saciar sua sede divina e, ao atingir a amplitude vital, se dilui na imensidão, ultrapassando o transitório. $\mathrm{O}$ eu lírico busca no rio e no mar o movimento dinâmico e permanente que supera o fim e retorna à indefinição do princípio. Ele busca encontrar a fonte e a foz a um só tempo, em um só movimento; procura chegar à amplidão da costa reiterando a continuidade das ondas, da espuma que banha a terra em eterna cadência:

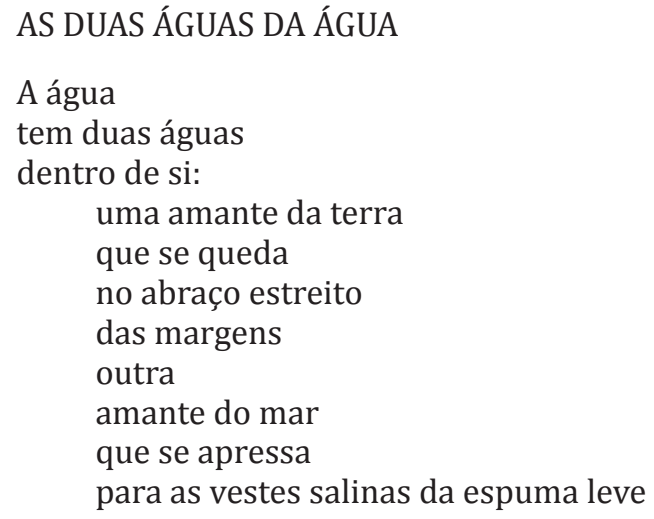

No mesmo rio viajam

duas vontades

entre o breve espaço

de ser fonte e foz.

Maputo, 76 (COUTO, 1983, p. 18).

Outro poema exemplar dos dois primeiros livros de poesia de Mia Couto, que continua a destacar o elemento Índico, é "Fundo do mar", que reproduzimos:

\section{Fundo do mar}

Quero ver

o fundo do mar

esse lugar

de onde se desprendem as ondas

e se arrancam

os olhos aos corais

e onde a morte beija

o lívido rosto dos afogados

Quero ver

Esse lugar

Onde se não vê

Para que

Sem disfarce

A minha luz se revele

E nesse mundo

Descubra a que mundo pertenço

Janeiro 1981 (COUTO, 1999, p. 49).

Ao longo dos versos, verificamos que, na primeira estrofe, o fundo do mar surge como um espaço de morte, enquanto, na estrofe seguinte, torna-se um local que fará o eu lírico conhecer o seu lugar no mundo, pois é nele que se revelará. Ambas estrofes iniciam com o mesmo verso: "Quero ver", demonstrando a vontade de o eu lírico enxergar aquilo que talvez lhe seja interdito ou para o qual ainda não esteja pronto para conhecer. É possível cogitarmos isso pelo movimento presente nos últimos versos em que há uma vontade desse eu lírico se expor, "pertencer", ou (re)nascer: "Para que/ Sem disfarce/ A minha luz se revele/E nesse mundo/ Descubra a que mundo pertenço" (COUTO, 1999, p. 49). Em "Fundo do mar", o mar é apresentado como contendo um infinito, como tendo as águas que diluem as vivências quando beija os rostos daqueles que lá chegaram. 
Em "Poema mestiço", que consta de Raiz de orvalho e outros poemas (COUTO, 1999, p. 58) e reaparece, mais recentemente, na obra Poemas escolhidos (COUTO, 2016, p. 109) ${ }^{11}$, coletânea selecionada pelo autor e publicada no Brasil em 2016, o poeta segue abordando a imagem do mar/oceano, ampliando seu significado:

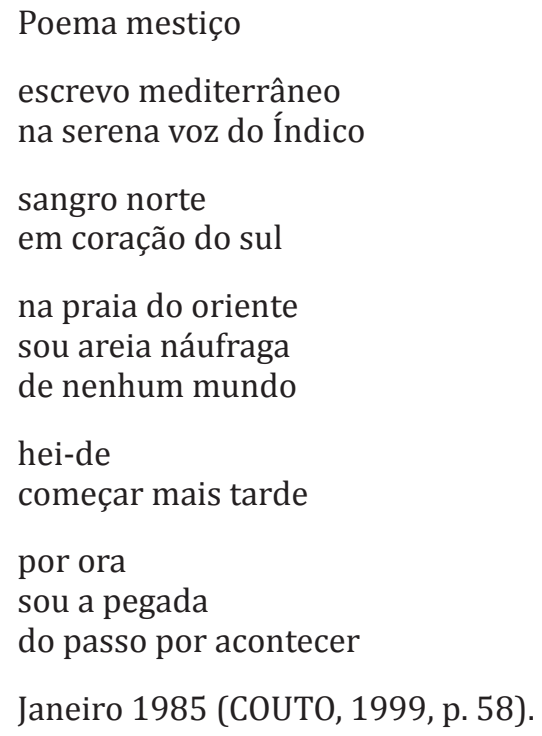

O poema apresenta o Índico com sua praia e sua areia náufraga como marcas de um caminho que segue até $\mathrm{o}$ - ou pelo - oceano. 0 eu lírico assume a escrita que traduz o Índico como uma voz que revela a procura pelo futuro. A memória pessoal traz à geografia moçambicana o portal de entrada e de saída: o Índico da História do seu país e da sua poesia. O mar conduz o poeta do exterior para o interior do seu mundo de promessas a cumprir. A longa

${ }^{11}$ Constam da obra, poemas selecionados dos livros: Idades cidades divindades, Raiz de orvalho e outros poemas e Tradutor de chuvas. busca realizada na intimidade - que se figura ampla por conter o "norte" e o "sul" - se expande nas areias "náufragas" que marcarão as pegadas do futuro do poeta e de Moçambique.

A presença do oceano Índico é uma constante na produção miacoutiana. Sua importância ultrapassa a justificativa de ser um dos três oceanos que banham a terra, mas encontra explicação em ser aquele que banha Moçambique. O Índico espelha o passado de chegadas no reflexo do que há de aportar, num diálogo entre a linearidade e a circularidade do tempo. A perspectiva do eu lírico dialoga intensamente com o romance $O$ outro pé da sereia (2006a), possuidor de uma estrutura narrativa alicerçada sobre dois eixos temporais distintos (janeiro/fevereiro de 1560 e dezembro de 2002), em capítulos não sequenciais, que seguem tanto uma alternância, quanto uma rotação. 0 trânsito entre os tempos (passado e presente) se faz entre ocorrências historicamente registradas e acontecimentos imaginados, através do relato ficcional. $\mathrm{O}$ texto formula diferentes viagens que imbricam tempo, espaço, História, mito, religião, identidade individual e coletiva sob a constante presença do elemento simbólico água.

Outro registro que une a areia e a terra, o Índico e Moçambique, está em "Sotaque da terra" que integra Raiz de orvalho e outros poemas (COUTO, 1999, p. 63) e, também, Poemas escolhidos (COUTO, 2016, p. 114):

$$
\begin{aligned}
& \text { Sotaque da terra } \\
& \text { Estas pedras } \\
& \text { sonham ser casa } \\
& \text { sei } \\
& \text { porque falo } \\
& \text { a língua do chão } \\
& \text { nascida } \\
& \text { na véspera de mim } \\
& \text { minha voz }
\end{aligned}
$$


ficou cativa do mundo,

pegada nas areias do Índico

agora,

ouço em mim

o sotaque da terra

e choro

com as pedras

a demora de subirem ao so

Junho 1986 (COUTO, 1999, p. 63).

A primeira imagem percebida, no poema, forma-se com a aproximação de "pedras" e "casa". A dureza da rocha se abranda ao ser associada ao aconchego da casa, um espaço de intimidade e refúgio. Esse conhecimento da vontade da pedra, por parte do eu lírico, logo é por ele explicado como resultante de seu conhecimento da "língua do chão" (COUTO, 1999, p. 63). Ou seja, o eu lírico fala uma língua primordial, possivelmente anterior àquela dos homens; havendo a certeza de que sua voz é anterior ao seu próprio nascimento, pois é "nascida/na véspera de mim" (COUTO, 1999, p. 63). E essa voz da qual faz uso está plena da terra de seu país por estar impregnada das areias do Índico, o qual se alarga com seu choro ao perceber que as pedras - mencionadas no primeiro dístico - não conseguem concretizar seu sonho, sendo ainda embriões ou sementes cobertas pela areia a espera de nascerem ou florescerem com seu país. Portanto, ao falar e/ou ao escrever, suas palavras têm o "sotaque" (COUTO, 1999, p. 63) de Moçambique, explicando-se a importância que ele - eu lírico/poeta - dá às questões de sua terra, o que acaba configurando o presente poema não apenas como possuidor de imagens/matrizes recorrentes em sua produção, mas como metapoético efetivamente.

Salientamos que a recorrência do Índico, na obra de Mia Couto, pode ser compreendida pela importância que essas águas têm para Moçambique.
É por meio delas que os sujeitos podem entrar e sair do país; por elas, as diferentes culturas chegaram e buscaram se estabelecer, promovendo o embricamento do local com o estrangeiro. As navegações marítimas igualmente se utilizaram do Índico para acessar a colônia. As viagens feitas por suas águas podem se traduzir na poesia, na prosa de curta ou de longa extensão. A comprovação disso se dá ao compararmos, por exemplo, os seus livros de poesia, nos quais a viagem na/pela água é recorrente, como nos versos do poema "Raiz de orvalho e outros poemas": "ofereço o mar/que em mim se abre/à viagem mil vezes adiada"12 (COUTO, 1999, p. 39), ou em "Maresias, quase saudades": "De quem fui onda,/ sou agora espuma, / búzio sem eco,/ lembrança de viagem nenhuma” (COUTO, 2014, p. 138).

Seguindo o campo semântico relacionado à água, o rio é outro elemento constante. Por vezes, sua presença em um único verso gera uma simbologia que se estende ao longo do poema, ao mesmo tempo que capta outros significados que a multiplicam, como podemos verificar no poema seguinte, publicado em Idades cidades divindades (COUTO, 2007):

\section{SEM DEPOIS}

Todas as vidas gastei para morrer contigo.

E agora

esfumou-se o tempo

e perdi o teu passo

para além da curva do rio.

Rasguei as cartas.

Em vão: o papel restou intacto.

Só os meus dedos murcharam, decepados.

${ }^{12}$ O poema "Raiz de orvalho" encontra-se nas edições de 1983 (COUTO, p. 51-54) e 1999 (COUTO p. 39-41). 
Queimei as fotos.

Em vão: as imagens restaram incólumes

e só meus olhos

se desfizeram, redondas cinzas.

Com que roupa

vestirei minha alma

agora que já não há domingos?

Quero morrer, não consigo.

Depois de te viver

não há poente

nem o enfim de um fim

Todas as mortes gastei

para viver contigo.

Maputo, 2006 (COUTO, 2007, p. 32-33).

Nos versos de "Sem depois", a morte simbólica, o desejo de morrer e o viver são presenças que atravessam o poema. Em um primeiro momento, o eu lírico fala do tempo que depreendeu de sua vida para com um outro, mas que por razões não explícitas acabou frustrado, como morto. Esse tempo gasto mostrou-lhe o descompasso entre si e o ser amado: "perdi o teu passo/ para além da curva do rio." (COUTO, 2007, p. 32) e as ações praticadas na tentativa de se desfazer de quaisquer objetos que lhe lembrassem de quem devotou afeto. Cartas foram rasgadas, fotos foram queimadas. Tudo em vão, pois sua memória mantém-se intacta, e incólume, independente da presença da concretude daquele sentimento. Tanto as cartas quanto as fotos contêm verdades, as quais o eu lírico não consegue se desapegar ou esquecer. Nem mesmo a vontade de morrer ele é capaz de efetivar.

$\mathrm{O}$ ato de ter vivido pelo/no outro mostrou-lhe que não há como separar sua existência das emoções sentidas. Sua vida se pautará nesse eterno sofrimento que é estar longe do outro e, assim, quase morrer; ao mesmo tempo que ter experienciado sentimentos profundos o farão viver para sempre com o outro. O eu lírico deixa claro que "Depois de te viver/ não há poente/ nem o enfim de um fim” (COUTO, 2007, p. 33). Este ciclo infinito é explicitado ainda pela construção do poema, possuidor de uma forma circular em que a primeira e última estrofes são praticamente iguais. A diferença entre elas consiste apenas em uma conter o verbo "morrer" e a outra, o "viver", os quais no contexto africano, não são vistos como antíteses, mas como estágios contínuos da existência, havendo inclusive um existir no morrer.

Essa explanação se potencializa com a imagem "para além da curva do rio", presente na segunda estrofe. A expressão que, com alguma variação, é recorrente na obra miacoutiana, carrega consigo concomitantemente a ideia de morte e de vida. Nos rios há sempre uma curva que conduz ao desconhecido, o além, que existe numa misteriosa presença desconhecida, fluída e, também, onírica. Esse sentido aparece, por exemplo, no conto "No rio, além da curva" (COUTO, 2003a, p. 95-101), quando, primeiramente, no sonho da personagem Jordão (um matador de hipopótamos), conforme nos conta o narrador, o dilema entre matar o simbólico bicho ou deixá-lo viver se faz presente:

Jordão sonhava com os animais, pareciam canoas viradas do avesso na lenta superfície do rio. E ele, no sonho, montava-lhes os dorsos e subia o rio, além da curva. Esse era o devaneio maior: descobrir o adiante da humana paisagem, encontrar o lugar para além de todos os lugares (COUTO, 2003a, p. 99-100).

Adiante, ao final da história, o narrador relata a partida do matador de Jordão, agora não mais um caçador de hipopótamos, mas um homem que vai realizar a sua travessia para outra vida, num recomeço que está no nascedouro do rio para onde se vai ao contrário da corrente: 
Em gesto brusco, como se se despedisse de uma parte de si, lançou a espingarda no rio. Foi nesse momento que escutou a humana voz. Vinha de onde? Vinha do pequeno filhote que salvara:

- Sobe naquela canoa virada.

Canoa? Aquele espesso volume acima da superfície? A voz repetia o convite:

- Vem. Eu te mostro o rio além da curva.

Então, já tornado encantável, o desarmado Jordão subiu o dorso húmido do sonho e extravagou-se pelo avesso da corrente (COUTO, 2003a, p. 101).

Neste conto, o diálogo da vida com a morte aparece ora como ruptura, ora como continuidade, o que remete às vidas gastas para morrer de que fala o eu lírico do poema, ao transpor para o onírico a passagem de uma instância para outra. A presença do sonho potencializa o rompimento com o real - que, no conto, é simbolizado pela arma de fogo que é lançada a favor da corrente que segue o curso do rio e do tempo -, libertando a personagem Jordão no mesmo estágio em que o eu lírico do poeta busca a inversão da morte para a vida.

Outro exemplo pertence ao capítulo "Um burro enigmático", de Um rio chamado tempo, uma casa chamada terra (2003b), em que a expressão "além da última curva do rio" conduz à ideia de que ao longe, onde não vemos, há mistérios desconhecidos que o quadrúpede convida o narrador a desbravar:

A presença do animal me tinha intrigado. Tanto que, de noite, o bicho tinha espreitado meu sonho. Não fora pesadelo. Olhar de burro está sempre acolchoado de um veludo afectuoso. Mas aqueles olhos eram mais do que isso. Possuíam humaníssima expressão e me convidavam para travessias que me inquietavam, bem para além da última curva do rio (COUTO, 2003b, p. 95).

O romancista Mia Couto traz as águas do rio, a morte no coletivo, num naufrágio que presencializa os vários tempos que transcorrem numa ilha e que envolvem os que partiram e os que ficaram, os que naufragam e os que lá habitam. Estes com suas narrativas de nascimento e morte guiados pelas águas correntes registram e mesclam o tempo linear, com o tempo circular e o tempo de sonhar. $\mathrm{O}$ burro trazido pelo naufrágio é o marco entre o sonho e a realidade, e desperta com seus olhos de "humaníssima expressão" o olhar do homem para o além da paisagem, o que significa, mais uma vez, ir para além da curva do rio.

O rio como um local da transição entre os estágios do viver e morrer também é percebido no poema "A metafísica de Silvestre Vitalício" (COUTO, 2007, p. 70-72), no qual localizamos um léxico vinculado à água/ao rio assim como à natureza ao seu redor:

\section{A METAFÍSICA DE SILVESTRE VITALÍCIO}

Para o velho Silvestre Vitalício

toda a metafísica se resume assim:

o Universo

é demasiado grande para ser criado

e o homem nasceu de um caniço.

Temos raiz num rio

e é por isso que o mar

nos dá a tristeza de um destino.

Para o velho Silvestre

Não há a Morte. Apenas os mortos existem.

A alma é uma sombra

sem terra onde desaguar.

Por isso,

Silvestre Vitalício

não entende porque

para mim,

o Universo não possa caber,

inteiro, no seu suspiro. 
Diz ele

que eu não sei das coisas sem tamanho.

Nem ele percebe

porque não quero morrer

junto a um rio de imensos canaviais

e ali deitar a alma

como quem, na corrente, solta uma canoa.

Para mim

Silvestre a metafísica é esta: Vitalício,

meu velho amigo Vitalício, está morrendo

e a minha mão é uma sombra

sobre o seu agonizante rosto.

Vai partir

e me pede que não lhe feche os olhos.

Não é ele quem vai dormir.

A folha dorme,

a semente sonha.

Os pés inchados

sobram dos últimos sapatos.

A areia presa à sola

é a única terra que o irá cobrir.

Boane, 2006 (COUT0, 2007, p. 70-72).

Um dos primeiros aspectos a destacarmos consiste no nome do sujeito com o qual o eu lírico estabelece um diálogo: Silvestre Vitalício. "Silvestre" trata-se daquilo que está ligado à natureza mais agreste, já "Vitalício" é aquilo que dura ou está predestinado a durar infinitamente. Assim, o eu lírico se relaciona com um homem que traz em si a marca da perenidade, a qual é reforçada pelo adjetivo "velho" que lhe acrescenta as noções de sabedoria e conhecimentos comumente associados à velhice. A sua eternidade está acoplada ao rio e ao seu universo aquático: "e o homem nasceu de um caniço" (COUTO, 2007, p. 70). A afirmativa determina uma origem; não só ele, Silvestre Vitalício, mas todos os homens surgiram dessa planta - portanto da natureza - que se encontra no rio, na divisão entre a água límpida daquela barrenta. Essa assertiva se mostra verdadeira quando o eu lírico afirma que "Temos raiz num rio" (COUTO, 2007, p. 70) e que, por isso, o mar é o fim a ser alcançado. A intuição que temos sobre a "tristeza de um destino" (COUTO, 2007, p. 70) busca explicação na consciência de que não há como fugir daquilo que foi designado ao ser humano ${ }^{13}$.

Fica evidente que as elucubrações do poema em pauta não se centram em pensar no corpo físico, mas na morte conectada à vida, como estágios que se sucedem e nos quais as almas vivem: "Não há Morte. Apenas os mortos existem" (COUTO, 2007, p. 70). Nas palavras de Vitalício, o viver é uma espécie de morrer, uma verdade que está muito além da compreensão do eu lírico: "[...] eu não sei as coisas sem tamanho" (COUTO, 2007, p. 71). Se, por um lado, a alma assemelha-se a uma sombra, por outro, ela também tem uma natureza aquática por "desaguar" (COUTO, 2007, p. 70). Entre as simbologias das águas, lembremos de sua capacidade de purificação e de rejuvenescimento que conduz ao eterno.

Quando Vitalício pede ao seu interlocutor que não lhe feche os olhos ao morrer, designa sua vontade de continuar a enxergar na nova etapa de sua existência. A última estrofe explicita que ao morrer ele não irá desparecer

${ }^{13}$ Essa certeza de que a origem do ser humano está no caniço, e assim junto ao rio, ecoa em um dos textos de prosa do autor. No livro já citado Um rio chamado tempo, uma casa chamada terra, no capítulo "A revelação" (COUTO, 2003b, p. 227-240), durante a ação de um sepultamento, é o coveiro - indivíduo próximo à morte - que propicia ao narrador protagonista executar com um caniço um movimento que simboliza o nascimento do homem, seguido de um ritual que se assemelha ao batismo, sem que haja o processo de purificação do sujeito, mas o contrário disso:

- Quais papéis? - insiste Curozero.

Respondo num gesto calado, de mãos vazias. O coveiro salpica com água as paredes do buraco. Cobrimos a sepultura de terra de mãos vazias. O coveriso sac pobrimos a sepultura de terra. Muando, descalço, pisoteia o chão, alisando a areia. Em seguida, por cima da campa espalha uns pés de ubuku, dessas ervas que só crescem junto ao rio. No fim, entrega-me um caniço e ordena que o espete na cabeceira da tumba. Foi um caniço que Como uma bandeira, o caniço parece envaidecido, apontando o poente.

- Agora, lavemo-nos nas águas do rio.

- Agora, lavemo-nos nas águas do rio. conspurcar. Todavia, cumpro o ritual, preceito a preceito (COUTO, 2003b, p. 240, grifos nossos). 
(por meio do sepultamento), e a areia - que pertence à esfera da margem do rio - presa à sola dos sapatos o fará lembrar de onde veio e quem foi, no seu existir vivo. $\mathrm{O}$ rio continua a percorrer a esteira da vida e da morte, continua a sediar a passagem de um estágio para outro e a prenunciar o tempo vindouro. Permanece claro que tanto o poeta quanto o prosador Mia Couto, circulam em esferas semelhantes ao assumirem as múltiplas travessias que as águas podem propiciar.

Para encerrar nossa sequência de análises, continuamos com a imagem do rio em "A condenação", poema que encerra o livro Idades cidades divindades (COUTO, 2007, p. 119-121) e que aparece também em Poemas escolhidos (COUTO, 2016, p. 81-83), carregando no próprio título o anúncio de uma pena a ser executada, ou seja, há uma informação de morte ligada ao rio:

\section{A CONDENAÇÃO}

Cansado da poesia,

o poeta levou os seus poemas

para junto do rio.

Queria rasgar os versos

um por um,

dilacerar a palavra,

truncar a ideia, desfibrar o coração.

Para o fim da poesia

procurou um rio que não tivesse nome

Teria que ser assim:

junto ao rio sem nome.

Nele afogaria a letra,

dissolveria a tinta,

liquefaria rima e metáfora.

Andou, cirandou: mas onde quer

que corresse um fio de água

fluía junto um nome

como se toda a água nascesse da palavra.
Deu volta ao mundo,

chegou onde não havia mais mundo:

em nenhum lado

figurava o inominado riachinho.

Cansado,

o poeta regressou à sua aldeia

e reincidiu na sua inicial angústia.

Ali, no pequeno ribeiro de sua terra natal,

ele sentou o seu desespero

e decepou os cadernos

desmembrou a escrita

e afogou os papéis

até que deixaram de respirar.

Chegou-se um peixe

e, de um golpe, comeu um verso.

No seguinte instante,

lhe cresceram asas

e o peixe soltou um voo de garça

para ganhar os vastos céus.

Dos papéis

que restavam em suas mãos

emergiu um braço de mulher

que, em dissolvente carícia

por sonhos o fez viajar.

Nessa noite,

de regresso a si mesmo,

o poeta

escreveu derradeiros versos

para matar de vez a poesia.

Acedeu, por fim,

à pequena morte do sono, desconhecendo

que, mesmo adormecido,

dentro de si

seguia fluindo

o único rio sem nome.

Boane, 2005 (COUT0, 2007, p. 117-121) 
Conforme anunciado, nesse poema, temos a notícia da morte. Morte dos poemas escritos pelo poeta que, por meio dos atos de violência elencados contra a palavra, ao querer dilacerá-la e rasgar os versos onde se encontra, mostra um desejo de negação ao que está dito, ao existente. O rio surge como o espaço onde efetuará o aniquilamento descrito.

A escolha pelo rio, não é aleatória. Sobretudo na quarta e quinta estrofes, é especificado que o rio e a palavra encontram-se em simbiose, um surgindo do outro. Ao partimos da premissa que o ato de nomear torna algo existente, a busca infrutífera do poeta pelo rio inominado revela que esse só existe ao ser nomeado. Portanto, não há como o poeta destruir a palavra sem que ela já tenha cumprido sua missão que é de dar vida ao rio.

A água 'geográfica' que pode ser, por exemplo, mar, oceano, lago, lagoa, rio, só ganha essas formas ao receber tais nomeações. A semelhança com o conto "Saíde, o lata de água" (COUTO, 2006b, p. 88-92) é grande. Nele o narrador percebe que "a água aceita a forma de qualquer coisa, não tem a própria personalidade" (COUTO, 2006b, p. 88). Ou seja, tanto no conto quanto no poema, as águas mostram o visível de suas formas somente quando recebem um contorno.

Em "A condenação", não podemos deixar de referir que, ao retornar à sua origem, no momento em que o poeta intenta a destruição de seus cadernos, da sua escrita e dos seus papéis no ribeiro, permite à palavra, no contato com a água, a obtenção de novos significados que transformam o ambiente em que se encontra. A imagem do peixe que muda sua essência ilustra isso. Além disso, é da palavra que surge o alento para o sujeito percebido pelo braço da mulher que o fará voltar a escrever na tentativa novamente frustrada de "matar de vez a poesia" (COUTO, 2007, p. 121). O sono, na última estrofe, aponta para a impossibilidade de eliminar a palavra e, por extensão, o ato de sua escrita. É nele que existe o rio sem nome, assim, ele é o ser ainda não existente, não nomeado e que precisa encontra o seu 'eu'.
O poeta que peregrina em busca do rio sem nome para desfazer o poema e matar a poesia não realiza o seu intento, pois, como afirma Octávio Paz (1982), “Um poema é uma obra, [...] é criação [...] é um organismo verbal que contém, suscita ou omite poesia” (PAZ, 1982, p. 18). Paz, teórico, crítico literário e poeta, sintetiza a grandeza do ato de criação poética ao dizer que “O poema não é uma forma literária, mas o lugar do encontro entre a poesia e o homem" (PAZ, 1982, p. 18), o que preenche os dizeres de Mia Couto, quando este expõe a sua submissão ao domínio criativo da poesia:

Eu estou sempre lá na poesia. Não vejo diferença, faço prosa e poesia. Quando decido contar uma história, romance ou conto, acontece em poesia, só. É um estorvo. Quero contar uma história e ter a disciplina de romancista e lá está a poesia. Agora, olhando para a chuva na janela, a poesia é uma chuva que limpa o céu e torna a alma limpa. Vou para o romance sem saber como vai ser a história. É como se a poesia me ajudasse de olhar a história (GIRON, 2014) ${ }^{14}$.

Mediante as análises realizadas ao longo desse artigo, envolvendo poemas e algumas breves considerações sobre suas relações com a prosa - curta ou longa -, percebemos que a água e os termos que se localizam em seu campo semântico têm uma importância decisiva não apenas para a estética miacoutiana, mas revelam sua concepção de mundo como homem moçambicano e universal. Nosso recorte de estudos, no "fazer" literário do autor, prioriza a presença da água como matriz temática, o que comporta múltiplas leituras dos significados ocidentais, mas também metaforiza os sentidos locais. Na África da escritura miacoutiana, essa matriz revive o espaço da nação, simboliza a passagem do tempo, gera e encerra ciclos de vida, representa purificações, apagamentos, destruições e regenerações e possibilita, além de duplicidades, deslizamentos de significações.

${ }^{14}$ Entrevista concedida a Luís Antônio Giron, publicada na Revista Época, sob o título "Mia Couto 'O português do Brasil vai dominar'”, em 2014. 
Mia Couto é, certamente, um inovador, um (re)criador e um espírito transgressor. Ao trabalhar a palavra, demanda toda uma forma artesanal que, na poesia, ele denomina como filigrana ${ }^{15}$. O próprio escritor discorre sobre isso, já em 1992, ao ser entrevistado pelo catedrático francês Michel Laban:

Penso que talvez esteja também mais presente o meu percurso: a minha passagem pela poesia talvez esteja mais presente na criação de novos vocábulos. Penso que são resultado da minha passagem por este trabalho de filigrana, de tratamento quase artesanal de palavra a palavra que penso que só a poesia nos pode ensinar. [...] a poesia como exercício é ela que te educa a cuidar parcela por parcela, este rendilhado. Penso que quem nos ensina a tecer é a poesia (LABAN, 1998, p. 1020) ${ }^{16}$.

A água compõe sínteses ilimitadas no tempo e no espaço, sendo uma especificidade da cultura moçambicana que reveste e/ou preenche a temática de Mia Couto. A água miacoutiana se materializa pelo rio, pela chuva, pelo mar/oceano e pelas lágrimas, imbricando espaços diferenciados e tempos distintos. A água do rio é o espaço onde as imagens da morte, da destruição, do renascer e do recomeço se configuram, egressas de fatos vivenciados por seres reais do cotidiano. É no movimento de ultrapassar margens e retomar seu espaço natural que o rio propicia a dinâmica de constituição da memória do "amanhã", no sentido universal, e do "sempre", no âmbito do contexto moçambicano. $\mathrm{O}$ rio miacoutiano é fundamento de sua própria história, conforme conta o cronista de "Natural da água", publicada em Cronicando (COUTO, 2003c, p. 77-78):

${ }^{15} \mathrm{Na}$ prosa, o filigrana abre um novo horizonte de significados na composição vocabular. Esses movimentos artesanais com a palavra, que traz a sua escrita o lirismo dos versos, formulam igualmente o tecido da prosa curta - conto - como preenchem as sucessivas páginas de um texto longo, isto é, de um romance.
um

${ }^{16}$ Entrevista com Mia Couto realizada em Paris, em 14 de fevereiro de 1992 e publicada em LABAN, Michel. Moçambique: encontro com escritores. Volume III. Porto: Fundação Eng. António de Almeida, 1998, p. 999-1035.
0 rio da minha infância: sotaque da terra, pronúncia da própria vida. Esse rio transcorre não no mundo mas em mim. Como se eu fora natural da água e não de lugar terreno. Às vezes flui manso, diluindo os amargos recantos, consolando as arestas da minha idade. Outras, fundo e espesso, quase imitando o fogo. Então, em sua corrente me ensombro. E me duvido: afogar é morrer na água ou no fogo? (COUTO, 2003c, p. 78).

O mar contendo a terra é o desafio permanente do homem, que nele percorre espaços, buscando traçar o curso da existência humana com suas flutuações de desejos e sentimentos (Cf. CHEVALIER; GHEERBRANT, 1996). Ele se contenta com pequenos barcos em meio a nevoeiros, recebe grandes navios que carregam sobrevivências e sobreviventes, derrotas e vitórias, correspondências e imagens, os invasores e os retornados, a vida que inicia e a que reinicia, a que evolui e a que se esvai. Mar eterno, perene no (re)nascimento e transformações, símbolo da dinâmica da vida, de acordo novamente com Chevalier e Gheerbrant (1996). O mar que abraça as terras é o mesmo que se mescla com a mais profunda emoção do homem e que dá inspiração ao eu lírico de todos os poetas.

Mia trabalha com as águas como um elemento básico para si e para seu país, reconhece a enorme malha de águas doces e salgadas que nutre as terras férteis, fornece a energia aos centros urbanos, abre os roteiros turísticos e comerciais, permitindo aos humanos que se adaptem às novas exigências para sobreviver. Ele congrega símbolos, sentidos e sentimentos num movimento de múltiplas facetas que traduzem o seu mundo particular e coletivo do qual faz parte. O percurso do mítico fundacional ao presente existente, as águas revivem e reavivam todos os percursos possíveis, manifestos nos mais diferentes domínios das palavras. As águas ultrapassam o cotidiano e se entregam ao poeta e prosador, que faz delas o alimento de sua escrita, espalhando-as pelo mundo na função de símbolo de vida e receptáculo da eternidade. 


\section{Referências}

BACHELARD, Gaston. A água e os sonhos: ensaio sobre a imaginação da matéria. Tradução de Antonio de Pádua Danesi. São Paulo: Martins Fontes, 2002.

BACHELARD, Gaston. A poética do espaço. Tradução de Antonio de Pádua Danesi. São Paulo: Martins Fontes, 2000.

BRUGIONI, Elena. Mia Couto: representação, história[s] e pós-colonialidade. Vila Nova de Famalicão, PT: Húmus, 2012.

CHEVALIER, Jean; GHEERBRANT, Alan. Dicionário de símbolos. 10. ed. Coordenação de Carlos Sussekind. Tradução de Vera da Costa e Silva et al. Rio de Janeiro: José Olympio, 1996.

COUTO, Mia. Cronicando. 7. ed. Lisboa: Caminho, 2003c.

COUTO, Mia. E se Obama fosse africano? e outras interinvenções. 2. ed. Lisboa: Editorial Caminho, 2009.

COUTO, Mia. Estórias abensonhadas. 7. ed. Lisboa: Caminho, 2003a.

COUTO, Mia. Jornal Expresso, Portugal. 12.04.2015. Disponível em: <http://expresso.sapo. $\mathrm{pt} /$ cultura/mia-couto-o-conto-que-ele-escreveu-para-o-expresso=f918758>. Acesso em: 12 set. 2017.

COUTO, Mia. Idades cidades divindades. 1. ed. Lisboa: Caminho, 2007.

COUTO, Mia. O outro pé da sereia. São Paulo: Companhia das Letras, 2006a.

COUTO, Mia. Pensageiro frequente. 3. ed. Lisboa: Caminho, 2010.

COUTO, Mia. Poemas escolhidos. 1. ed. São Paulo: Companhia das Letras, 2016.

COUTO, Mia. Raiz de orvalho. 1. ed. Maputo: Cadernos Tempo, 1983.

COUTO, Mia. Raiz de orvalho e outros poemas. 3. ed. Lisboa: Caminho, 1999.

COUTO, Mia. Repensar o pensamento, redesenhando fronteiras. In: MACHADO, Cassiano Elek (Org.). Pensar a cultura. Série Fronteiras do Pensamento. Vol. 1. Porto Alegre: Arquipélago, 2013. p. 195-206.

COUTO, Mia. Tradutor de chuvas. 1. ed. Lisboa: Caminho, 2011.

COUTO, Mia. Um rio chamado tempo, uma casa chamada terra. São Paulo: Companhia das Letras, 2003b.
COUTO, Mia. Vagas e lumes. 1. ed. Lisboa: Caminho, 2014

COUTO, Mia. Vozes anoitecidas. 8. ed. Lisboa: Caminho, 2006b.

GIRON, Luís Antônio. Mia Couto: "O português do Brasil vai dominar". Revista Época, 18.04.2014. Disponível em: <http://epoca.globo.com/ideias/noticia/2014/04/bmiacoutob-o-portugues-do-brasil-vai-dominar.html>. Acesso em: 12 set. 2017.

LABAN, Michel. Encontro com escritores. III v. Porto: Fundação Eng. António de Almeida 1998.

PAZ, Octavio. O arco e a lira. Tradução de Olga Savary. 2. ed. Rio de Janeiro: Nova Fronteira, 1982

SECCO, Carmen Lucia Tindó Ribeiro. Mia Couto e a "incurável doença de sonhar". In SEPÚLVEDA, Maria do Carmo; SALGADO, Maria Tereza. África \& Brasil: letras e laços. São Caetano do Sul, SP: Yendis, 2006. p. 267-298.

Recebido em 30/09/2017.

Aceito em 30/01/2018. 